\title{
Polymer meets ceramic: Polymer-driven advancement of ceramic 3D printing technology
}

\section{Chaenyung Cha}

School of Materials Science and Engineering, Ulsan National Institute of Science and Technology, Ulsan 44919, Korea

\section{고분자와 세라믹의 만남: 고분자를 통한 세라믹 3D 프린팅 기술의 발전}

\author{
차채녕 ${ }^{\dagger}$ \\ 울산과학기술원 신소재공학부 \\ (Received Febrary 23, 2020; Accepted March 17, 2020)
}

\begin{abstract}
s
The recent advances and popularity of 3D printing technology have centered around building polymerbased 'plastic' materials, due to their low cost, simple and efficient processing, and mechanical toughness. For this reason, printable polymers are actively recruited to create 'ceramic resins' that allow more facile fabrication of ceramic materials that are difficult to print directly. Herein, a brief history and the current state of ceramic 3D printing technology aided by polymer is summarized. In addition, a new ceramic 3D printing technology using polymer-derived ceramics (PDC) is also introduced.
\end{abstract}

Keywords: ceramic 3D printing, ceramic resin, polymer-derived ceramics

\section{1. 서론}

$3 \mathrm{D}$ 프린팅은 지난 10 년 간 과학기술계에서 가장 주 목을 많이 받은 기술 중 하나다. 기존 대량 생산에 적합 한 성형, 가공 방식보다 훨씬 더 정교하고, 자동화 방식 으로 편리하게 제품을 제작할 수 있는 장점으로 주목받
아왔다. 오바마 전 미국대통령이 2013년 국정연설에서 미래 육성 산업의 핵심으로 언급하면서, 전 세계적으로 $3 \mathrm{D}$ 프린팅 기술 보급 및 고도화에 주력해 오고 있다. 이 제는 일반인들도 누구나 쉽고 편리하게 사용 가능한 $3 \mathrm{D}$ 프린터 보급되고 있다. 그러나 $3 \mathrm{D}$ 프린팅 기술은 우리 가 생각하는 것 보다 더 긴 역사를 가지고 있다.

${ }^{\dagger}$ Corresponding Author: Chaenyung Cha

E-mail: ccha@unist.ac.kr 
(a)

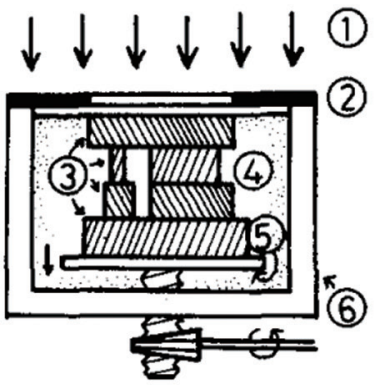

(b)

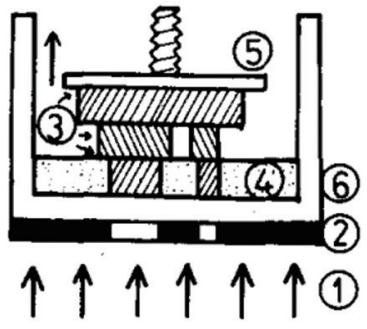

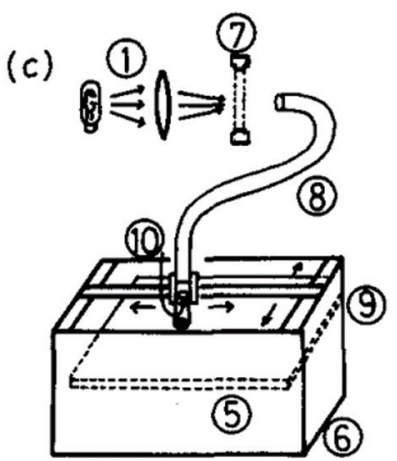

Fig. 1. H. Kodama (1981)가 개발한 photolithography 기술 도입한 3D 프린팅 모식도." (a) 상부 광경화 방식, (b) 하부 광경화 방식, (c) 광 스캐닝 방식.
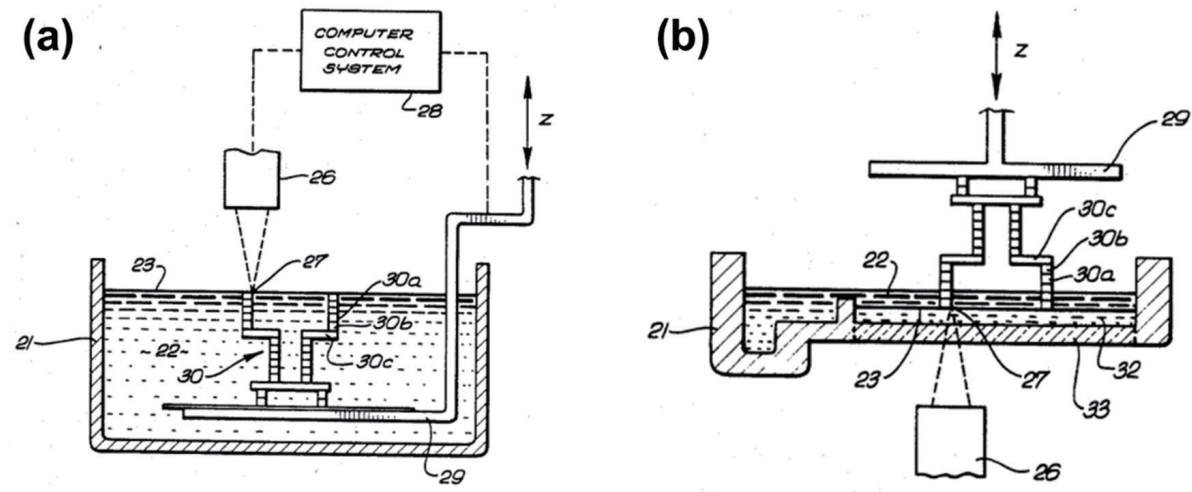

Fig. 2. C. Hull (1986)이 개발한 레이저 조사 방식 stereolithography (SLA) 기술." (a) 상부 광경화 방식, (b) 하부 광경화 방식.

현재 3D 프린팅과 가장 유사한 가공 방식은 $\mathrm{H}$. Kodama (1981년)에 의해 최초로 보고되었다 (Fig. 1). ${ }^{1)}$ 현재 널리 사용되고 있는 digital light processing (DLP)와 photolithography를 혼합한 방식으로, 액 상 광경화 레진(resin)에 미세패턴된 photomask를 통 해 자외선을 조사하여 한 면의 구조체를 제작하는 방 식이다. 또한 제작된 구조체 위에 반복된 제작을 통 해 최종적인 3D 구조체를 제작할 수 있다. DLP는 photomask 대신 digital micromirror array (DMD, Texas Instrument사 개발)를 통해 전자식으로 빛의 패 턴을 조절할 수 있다는 것이 유일한 차이점이다. ${ }^{2}$ 그 이 후 3D Systems사 설립자인 Charles W. Hull은 1986 년 stereolithography (SLA) 기술을 개발하여, 자외 선 레이저를 통해 보다 더 정교하고 원하는 패턴을 자동
화 방식으로 제작 가능한 $3 \mathrm{D}$ 프린팅 기술을 제시하였다 (Fig. 2). ${ }^{3)}$ 이와 비슷한 시기에 Carl Deckard는 SLA와 비슷한 방식인 selective laser sintering (SLS)를 개발 하였다. SLA와 달리 SLS는 강한 에너지를 가진 레이저 를 광원으로 사용하여, 보다 높은 온도에서만 용융-성 형이 가능한 금속 소재의 $3 \mathrm{D}$ 프린팅에 주로 사용된다.

고분자는 연성이 높고, 온도에 따른 용융/고화가 일정 하고, 그에 따른 기계적 물성이 연속적으로 변한다. 또 한 자외선과 같은 광 조사를 통해 광경화성 고분자의 라 디칼 중합반응을 유도하여 고체화가 가능하다. 그러므 로 현재 널리 사용되고 있는 열경화 및 광경화 기반 프 린팅 공정을 이용한 성형-가공에 매우 적합한 소재이 다. 이러한 장점들로 인해 최근 $3 \mathrm{D}$ 프린팅 기술의 엄청 난 발전은 대부분 저렴한 대량생산 가능한 범용 고분자 
를 원료로 한 '플라스틱' 소재 제작이 중심이 되어왔다. 금속 소재도 비슷한 열-기계적 특성을 가지고 있고, 레 이저와 같은 높은 에너지를 통해 용융/고화도 가능하기 때문에, SLS같은 기술을 통해 $3 \mathrm{D}$ 프린팅 가공이 가능 하다.

반면에, 세라믹 소재는 오랫동안 3D 프린팅 기술에 적합하지 않은 소재로 여겨져 왔다. 먼저, 세라믹 소재 는 연성이 거의 없고, 취성(brittleness)이 매우 높다. 그러므로 쉽게 깨질 뿐만 아니라 연속된 적층이 어렵 다 (층간 접합성이 낮음). 또한, 세라믹은 초기 구조체 를 제작하더라도, 이는 결정성이 낮고 결정립계(grain boundary)가 최적화되지 않기 때문에, 반드시 후처리 (탈지, 소결) 공정을 거쳐야 하는 번거로움이 있다. 또 한, 후처리 과정 이후 부피 변화가 수반되기 때문에, 원 래 크기와 정교함을 유지할 수 없게 된다. 이러한 이유 로 인해, 세라믹 $3 \mathrm{D}$ 프린팅은 다른 소재에 비해 기술 성 숙도가 낮은 것이 사실이다.

세라믹 소재의 $3 \mathrm{D}$ 프린팅 적용 부재는 응용 분야 및 산업화 가능성과도 밀접한 관련이 있다. 고분자와 금속 소재는 항공 우주, 자동차 산업 같은 중공업, 바이오메 디컬 산업 등 다양한 산업에서 소자-부품으로 개발되 고 있는데, 산업의 기술 고도화에 따라 전자 기계 분야 소자-부품의 구조적 복잡성을 구현하기 위한 공정의 정 교성이 더욱 더 요구되고 있다. 그러므로 기술 고도화에 따라 효율성 및 사업성을 보유한 3D 프린팅 기술이 속 속 개발됨에 따라 이를 도입하려는 많은 노력이 있다. 반면에, 세라믹 소재를 이용한 소자-부품 산업은 효율 적 대량생산이 복잡한 구조 구현보다 지금까지 더 중요 한 요소로 작용하여 왔다. 또한, $3 \mathrm{D}$ 프린팅을 응용하여 제작 가능한 복잡 구조 세라믹 소재의 산업적 수요가 현 재까지 크지 않기 때문에 관련 연구 개발이 더디게 진행 되는 점도 있다.

그러나 1990년대부터 세라믹 3D 프린팅 기술 발전을 위한 연구 개발이 지속적으로 이루어져 왔다. 특히 고분 자 기반 $3 \mathrm{D}$ 프린팅 기술의 비약적인 발전을 발판 삼아, 고분자와 세라믹을 혼합하는 형태의 기술로 승화시킨 세라믹 $3 \mathrm{D}$ 프린팅을 개발하여 발전을 거듭하고 있다.
본문에서는 현재까지 개발된 다양한 세라믹 $3 \mathrm{D}$ 프린팅 기술의 특징과 장단점 등과 세라믹 $3 \mathrm{D}$ 프린팅에서 고분 자의 역할을 소개하고자 한다. ${ }^{4-6)}$ 특히, 가장 최근 개발 된 고분자에서 세라믹으로 직접 변환 가능한 신개념 고 분자 유래 세라믹 (polymer-derived ceramics)을 이용 한 프린팅 기술을 통해 미래 세라믹 3D 프린팅의 방향 에 대해서 고찰하고자 한다.

\section{2. 셰라믹 3D 프린팅 기술의 시작과 발전}

세라믹이 가지는 낮은 연성, 높은 취성 등의 프린팅 공정에 적용하기 힘든 특성들을 극복하여 $3 \mathrm{D}$ 프린팅 기 술에 적용하기 위해 다양한 시도들이 현재까지 진행되 고 있다. 1980년대 SLA, SLS가 개발되면서, 이를 응용 하여 세라믹 소재를 프린팅 하려는 연구가 진행되었다. University of Connecticut의 Harris Marcus 교수 연 구팀은 SLS를 이용하여 세라믹 파우더 freeform 형태 로 프린팅하는 기술을 보고하였다. ${ }^{7)}$ 또, Massachusetts Institute of Technology의 Emanuel Sachs 교수 연구 팀은 잉크젯 프린터를 이용하여 실리카/알루미나 파우 더와 실리카 콜로이드 바인더를 혼합하여 분사하는 방 식의 세라믹 프린팅을 보고하였다. ${ }^{8)}$

이러한 세라믹 분말 소재만을 사용하는 프린팅 방식 은 크게 두 가지 단점이 존재한다. 첫째, 파우더 형태는 쉽게 분산되기 때문에, 경화 과정에서 형태 유지가 매 우 어렵다. 둘째, 한번 경화가 되면 적층을 통한 큰 규 모의 소재를 제작하기 어렵다. 그러므로 이러한 기술 적 한계를 극복하기 위하여, 1990년대 중반 University of Michigan의 John Halloran 교수 연구팀은 고분자 SLA 프린팅 기술을 세라믹 3D 프린팅에 응용하기 시작 하였다. ${ }^{9-11)}$ 실리카, 실리콘 니트라이드 $\left(\mathrm{Si}_{3} \mathrm{~N}_{4}\right)$, 알루미 나 파우더 등을 hexanediol diacrylate 레진에 분산시 킨 “세라믹 레진”이란 개념을 제시하였다. 이를 통해 해 상도가 높은 복잡 형상 세라믹을 제작할 수 있었다. 이 후, 세라믹 $3 \mathrm{D}$ 프린팅 기술은 세라믹 레진 개발을 중심 으로 지속적인 발전을 이루어 왔다. 

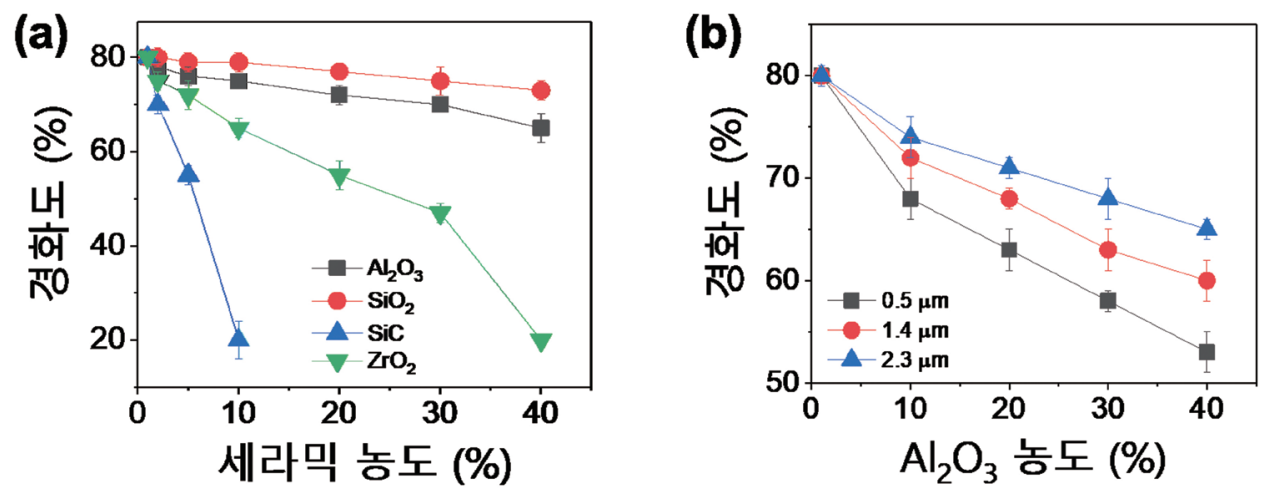

Fig. 3. 세라믹 분말의 물리적 성질에 따른 세라믹 레진의 광경화도 분석. ${ }^{2)}$ (a) 세라믹 농도, (b) 세라믹 (알루미나) 입자 크기 (직경).

\section{1. 광경화 세라믹 $3 \mathrm{D}$ 프린팅}

광경화 세라믹 $3 \mathrm{D}$ 프린팅의 핵심은 최적화된 세라 믹 레진 개발에 있다. 세라믹 레진의 가장 중요한 요소 는 액상 광경화 레진에 세라믹 분말을 안정적으로 분산 시키는 것이다. 이를 위해서는 분말 입자의 크기와 입 도, 표면의 화학적 성질, 분말의 농도 등 다양한 레진의 물리적 성질의 최적화가 필수적이다. 예를 들어, 입자간 응집력이 입자와 레진간 결합력보다 높을 경우, 세라믹 입자들의 뭉침 현상이 발생하여 밀도가 일정한 세라믹 제작이 불가능하다. 이를 개선하기 위해서는 레진을 구 성하는 단량체, 고분자의 화학적 특성 및 용매 종류 등 을 조절해야 한다.

레진의 광학적 특성 또한 매우 중요한 요소이다. 소 결 시 수축을 최소화하고 고밀도 세라믹을 제작하기 위 해서는 레진 내 세라믹 분말 농도를 최대화하는 것이 중 요하다. 하지만 세라믹 농도가 높아질 수록 굴절율이 높 아지기 때문에 투과율이 낮아져 광경화 효율 (깊이, 해 상도)이 낮아지게 된다 (Fig. 3a). ${ }^{12)}$ 입자 크기 또한 중 요한 요소이다. 입자가 너무 클 경우 레진 내부에서 시 간에 지남에 따라 서서히 가라앉기 때문에, ball milling 등을 이용하여 입자 크기를 직경 수 마이크로미터로 줄 인 분말을 사용한다. 하지만 세라믹 입자는 광경화 과 정에서 레진과의 결합을 통한 필러 역할을 하여 더 강한 경화를 유도하게 되는데, 만약 입자가 너무 작을 경우, 레진과의 상호작용이 오히려 감소하여 경화도가 낮아지
는 역효과가 나타나기도 한다 (Fig. 3b).

광경화 레진의 최적화 또한 중요한 요소이다. 광경화 가 가능한 아크릴 계열 단량체 혹은 올리고머 등을 주로 사용하며, 이들의 농도 및 종류를 조절하면서 레진의 점 도를 조절한다 (Fig. 4). 아크릴 단량체는 농도뿐만 아 니라 분자 당 아크릴 작용기 개수에 따라서 가교 밀도 가 달라진다. 아크릴 작용기가 한 개인 단량체는 광경화 시 선형 고분자만 합성되므로 아크릴 작용기가 두 개 이 상인 “가교제”를 첨가해야 고분자 사슬 간 가교가 진행 되어 경화된다. 경화된 구조체의 기계적 강도는 단량체 와 가교제의 농도와 비율에 따라 조절된다. 단량체의 농 도가 높을 수록, 가교제의 비율이 높을수록 경화 속도가 높아지고 높은 강도의 구조체가 제작된다. 이는 제작되 는 구조체의 정교함과도 직결되어 있으므로, 매우 중요 한 요소이다. 하지만 경화속도와 기계적 물성의 계속된 증가가 항상 좋은 것 많은 아니다. 예를 들어 경화속도 가 너무 빠를 경우, 여러 층을 제작하는 과정에서 층간 접착력이 낮아질 수 있다 (다음 층 제작 전에 이전 층의 경화가 완료될 경우, 접착력이 떨어짐). 또한, 가교 밀도 가 높을수록 구조체 내부 공간이 협소해지므로 그만큼 채워질 수 있는 세라믹 양도 줄어든다. 그러므로 정교한 프린팅 공정에 영향을 주지 않으면서 세라믹 비율을 극 대화할 수 있는 레진의 가교밀도와 경화속도의 범위 설 정이 중요하다.

광경화 세라믹 $3 \mathrm{D}$ 프린팅은 대부분 현재 가장 널리 
<smiles>C=CC(N)=O</smiles>

1

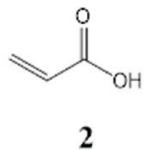

2

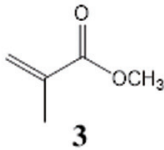<smiles>C=CC(=O)OCCOC</smiles>

4<smiles>C=CC(=O)OCCOC(C)=O</smiles>

6<smiles>C=CC(=O)OCC(CC)(COC(=O)C=C)COC(=O)C=C</smiles>

8<smiles>C=CC(=O)OC1CC2CCC1(C)C2(C)C</smiles><smiles>C=CC(=O)OCCCCCCOC(=O)C=C</smiles>

7<smiles>C=CC(=O)OCC(COC(=O)C=C)(COC(=O)C=C)COC(=O)C=C</smiles>

9
Fig. 4. 광경화 레진에 사용되는 아크릴 계열 단량체 예시. ${ }^{6)}$ 분 자 당 아크릴기 개수에 따라 가교밀도 조절 가능함. 1: acrylamide, 2: acrylic acid, 3: methyl methacrylate, 4: methyl ether poly(ethylene glycol) acrylate, 5: isobornyl acrylate, 6: poly(ethylene glycol) diacrylate, 7: 1,6-hexanediol diacrylate, 8: trimethylolpropane triacrylate, 9: pentaerythritol triacrylate

보급된 SLA와 DLP를 그대로 채택한다 (Fig. 5). ${ }^{13)}$ SLA 는 현재 가장 널리 사용되고 있는 광경화 방식의 $3 \mathrm{D}$ 프 린팅 기술이다. 광경화 가능한 어떤 레진도 적용 가능하 며, 레이저를 통해 고해상도 성형이 가능하고, 일반적으 로 사용하는 단층형 photolithography와 달리 적층 가 공까지 가능하기 때문이다. 이와 더불어, Hull이 1986년 에 최초 개발한 이후 설립한 3D Systems사에서 SLA를 판매하기 시작하면서 최초의 상용 $3 \mathrm{D}$ 프린팅 장비로 시 장을 선점하였기 때문이기도 하다. Halloran 교수의 초 기 연구 이후, SLA를 이용한 세라믹 3D 프린팅 연구가 하나의 큰 연구 줄기로 발전하였다. ${ }^{9-11)}$ 최근 Formlabs, 3D Systems, ExOne, Voxeljet 등 글로벌 3D 프린팅 회사들이 SLA에 적용할 수 있는 세라믹 레진을 상용화 하여 세라믹 $3 \mathrm{D}$ 프린팅 보급을 점점 앞당기고 있다.

$\mathrm{DLP}$ 는 SLA의 변형된 방식으로, 레이저 대신 $\mathrm{DMD}$ 를 (a)

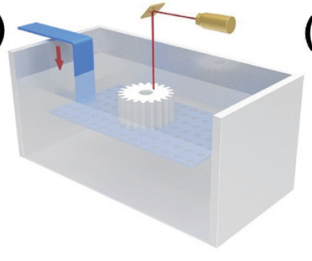

(b)

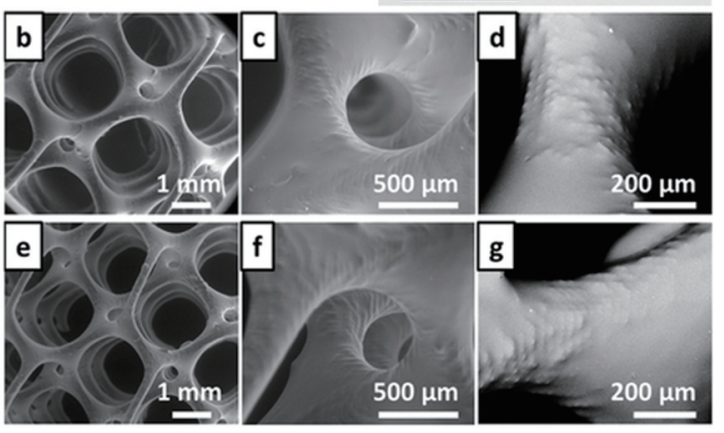

Fig. 5. (a) SLA 세라믹 3D 프린팅 기술. ${ }^{4)}$ (b) SLA 프린팅을 이용한 세라믹 구조체 예시. ${ }^{13)}$

(a)

(c)

(b)
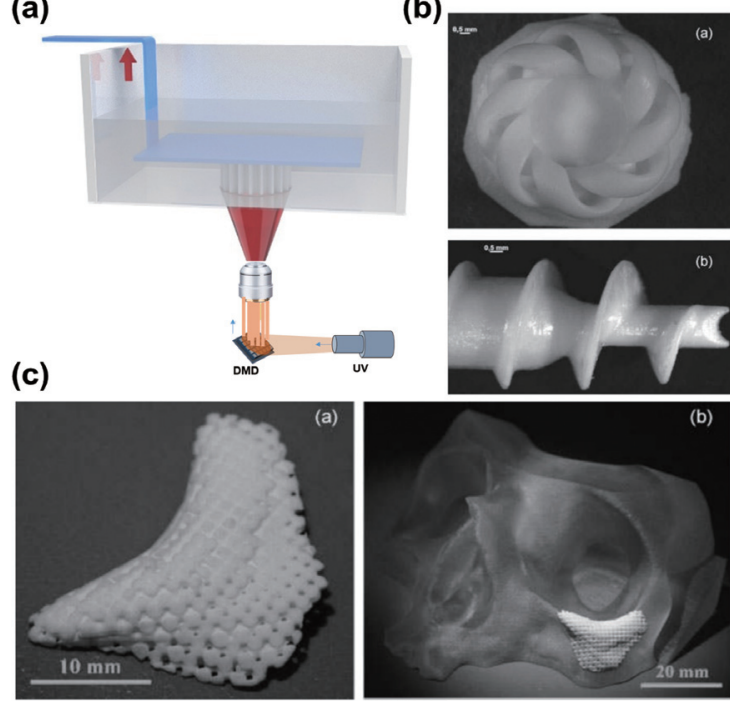

Fig. 6. (a) DLP 세라믹 3D 프린팅 기술. ${ }^{4)}$ (b, c) DLP 프린팅을 이용한 세라믹 구조체 예시. ${ }^{14)}$

통해 광 패턴을 조사하는 방식이다. $\mathrm{DMD}$ 의 수십만개 의 미세거울(micromirror)들을 통해 픽셀을 조절할 수 있어 해상도가 높고 한번의 광 조사에 넓은 면적을 경화 할 수 있는 장점이 있다. SLA와 같은 원리로 작동하는 $\mathrm{DLP}$ 역시 SLA와 마찬가지로 광경화성 세라믹 레진을 적용하여 다양한 세라믹 프린팅이 가능하다 (Fig. 6). ${ }^{14)}$

광경화 $3 \mathrm{D}$ 프린팅의 단점은 레진 수조(reservoir)에 
개발기술
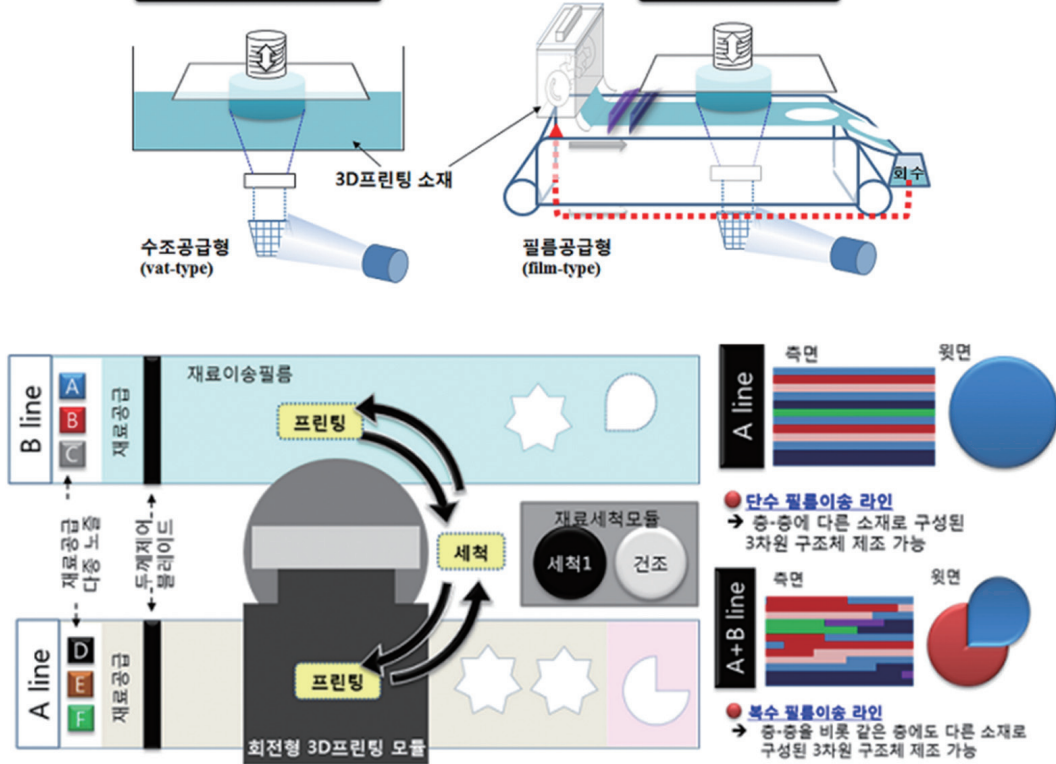

Fig. 7. 다종 세라믹 프린팅 기술 모식도 (재료연구소 윤희숙 박사 연구팀). ${ }^{15)}$ 기존 레진 수조가 아닌 필름형 레진의 자동 공급 방식으로 소재 낭비를 줄이고 다종(multi-material) 프린팅을 구현함.

많은 양의 레진을 넣어야 한다는 것이다. 레진 소비의 효율성뿐만 아니라, 수조에는 한 종류만 넣을 수 있기 때문에 다종 소재 프린팅이 어렵다. 최근 한국 재료연 구소 윤희숙 박사 연구팀은 이러한 단점을 극복할 수 있 는 '다종 세라믹 프린팅' 기술을 개발하였다 (Fig. 7). ${ }^{15}$ 기존의 레진 수조 방식과 달리 박막 필름 형태의 레진을 롤러로 연속적으로 공급하면서 광 조사를 통해 프린팅 하는 방식으로, 제작하고 남은 레진은 컬렉터로 모은 다 음 다시 필름 레진으로 재사용하는 방식으로 소재 낭비 를 막을 수 있다. 또한, 다른 종류의 세라믹도 필름 형태 로 공급 가능하기 때문에 다종 소재 프린팅도 쉽게 가능 하다. 이러한 장점들로 인해 기존 광경화 세라믹 $3 \mathrm{D}$ 프 린팅의 한계를 극복할 수 있는 신기술로 평가받고 있다.

\section{2. 열경화 세라믹 3D 프린팅}

Selective laser sintering (SLS)은 SLA와 함께 초 창기 $3 \mathrm{D}$ 프린팅 기술 개념을 정립한 주요한 기술로 써, 레이저를 통해 고온의 집적된 에너지를 분말 베드 에 조사하여 원하는 부분을 선택적으로 용융-소결하 는 방식이다 (Fig. 8). ${ }^{16-17)}$ 액상 레진을 사용하는 광경

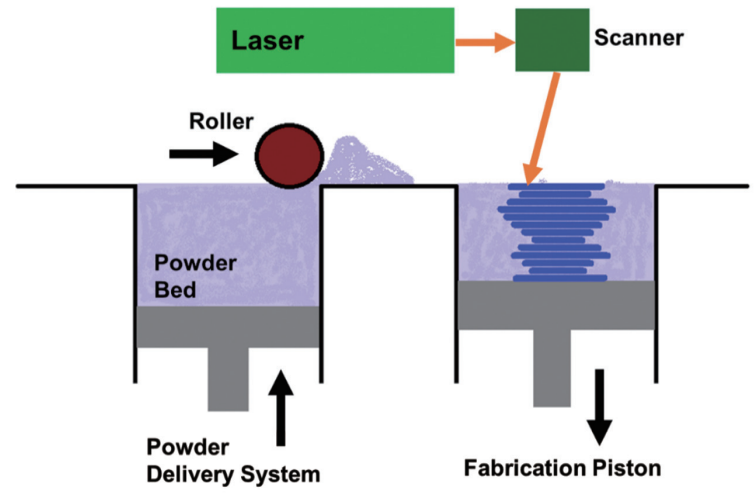

Fig. 8. SLS 세라믹 프린팅 기술

화 방식과 다르게 분말 형태의 원료를 사용하기 때문 에 초기에는 주로 티타늄, 알루미늄, 스테인레스강 등 과 같은 금속이나 광경화되지 않는 열가소성 플라스 틱 부품 혹은 모형 제작에 주로 사용되었다. 이후 세 라믹 분말을 원료로 한 SLS 세라믹 3D 프린팅 기술도 다양하게 시도되었다. 금속에 비해 세라믹 소재는 결 정립계와 같은 결함을 가지고 있어, 분말 상태에서 짧 은 시간의 레이저 조사 만으로 고밀도 소결이 어렵다. 그러므로 밀도가 상대적으로 높은 알루미나 혹은 지 


\section{특 집 ㅁㅁ 차채녕}

(a)

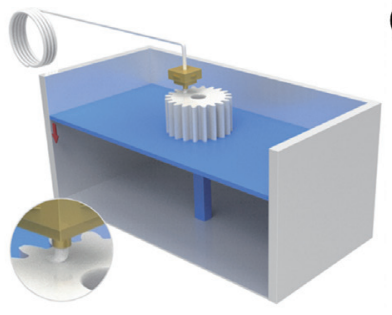

(b) (a)

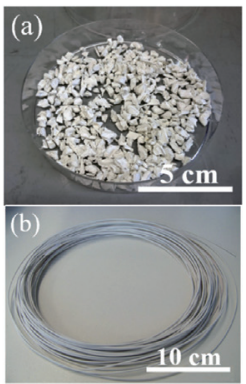

(c)

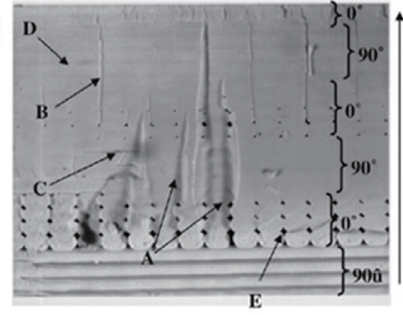

한 필라멘트로의 제작이 거의 불가능하기 때문에, 세라 믹 3D 프린팅용으로 널리 응용되지 않았다. 1995년 최 초로 $\mathrm{FDM}$ 을 이용한 세라믹 $3 \mathrm{D}$ 프린팅 연구를 보고한 이후, 미국 Rutgers University의 Stephen Danforth 교수는 Ahman Safari 교수와 함께 FDM ceramic 3D printing 분야 발전을 주도하였다. ${ }^{21-22)}$ 세라믹 파우더 를 고온의 고분자 바인더와 혼합한 다음, 필라멘트로 제 작하여 $\mathrm{FDM}$ 에 적용하는 방식으로, $\mathrm{SLS}, \mathrm{DLP}$ 와 같은 광경화 방식이나 SLS에 비해 정교함이 낮지만, 가장 널 리 보급된 $\mathrm{FDM}$ 프린팅에 쉽게 적용하다는 장점이 있다 (Fig. 9). ${ }^{23-25)}$

전자 부품과 같이 미세 정교함이 필요하지 않고, 가공 방식의 효율성과 가격 경쟁력이 높은 $\mathrm{FDM} \mathrm{3D}$ 프린팅 방식의 장점은 의료용 바이오세라믹 제작 응용으로 이 어지고 있다. 특히 정형외과, 성형외과, 치과용 골 이식 제품을 환자 맞춤형으로 제작하기 위한 "바이오프린터" 가 의료계에 널리 보급되고 있다. $\mathrm{FDM}$ 은 가는 필라멘 트를 오버레이하는 방식으로 필연적으로 필라멘트 사이 에 공간이 생기게 되는데, 이런 공간들도 모델링을 통해 크기와 배치를 조절할 수 있다. 이러한 '다공성' 구조는 정밀 부품 제작에 있어서는 단점으로 여겨지나, 골 조직 대체재로서는 주변 조직의 침습과 결합을 유도할 수 있 어 오히려 장점으로 작용한다. ${ }^{5,25-26)}$

르코니아 분말에 acrylonitrile-butadiene-styrene (ABS), polypropylene (PP), polyether ether ketone (PEEK), polycarbonate $(\mathrm{PC})$ 과 같은 고분자 바인더를 첨가하는 방식으로 밀도를 높이고 프린팅 해상도를 높 이는 방법론이 제시되었다. ${ }^{18-20)}$

최근 $3 \mathrm{D}$ 프린팅 기술의 보편화에 앞장 선 기술은 fused deposition modeling (FDM) 방식의 프린팅이 다. $\mathrm{FDM}$ 은 필라멘트 형태의 열가소성 고분자를 원료 로 이용하여 고온의 프린팅 헤드를 통해 순간적인 용융 으로 사출한 다음 저온에서 고화되는 간단한 방식의 프 린팅 기술로서, 대부분의 열가소성 고분자 소재를 적용 하여 플라스틱 제품을 제작할 수 있다. 그러므로 $\mathrm{ABS}$, $\mathrm{PLA}, \mathrm{PC}$ 와 같은 범용 플라스틱 제품의 프린팅에 매우 유용하다. 연성이 없는 세라믹 소재는 FDM 적용을 위

\section{3. 그분자의 직접 변환을 이융한 새로운 방식의 세라믹 3D 프린탕}

2016년 미국 HRL Laboratories의 Tobias Schaedler 박사 연구팀은 Science지에 “Additive manufacturing of polymer-derived ceramics”라는 제목의 논문을 발 표하였다. ${ }^{27)}$ 기존 세라믹 $3 \mathrm{D}$ 프린팅은 세라믹 분말 기 반의 레진을 주로 사용하는데, 소결/탈지 과정에서 고분 자 부분이 제거되면서 밀도가 낮아지며, 국소적인 열 혹 은 광처리 과정에서 gradient가 생겨 일정하지 않은 기 계적 물성 등의 큰 단점들이 있다. 이를 극복할 수 있는 하나의 방안으로, Schaedler 박사 연구팀은 세라믹 분 말 없이 광경화 가능한 전세라믹 고분자 (pre-ceramic 


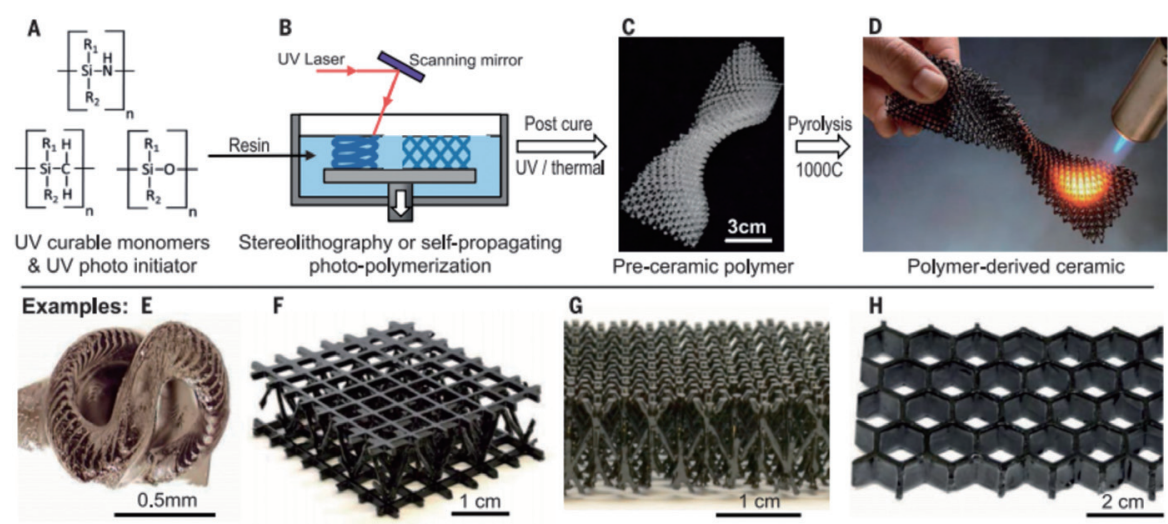

Fig. 10. 전세라믹 고분자(PCP)를 이용한 고분자 유래 세라믹(PDC) 3D 프린팅 기술.(27) 광경화 가능한 유기실리콘 고분자를 SLA를 통해 구조체를 제작한 후, 소결과정을 통해 세라믹 분말 없이 PDC를 제작함.

polymer, $\mathrm{PCP}$ )를 직접 $3 \mathrm{D}$ 프린팅하는 기술을 제시하 였다 (Fig. 10). PCP를 세라믹 분말 없는 레진으로 사용 하여, 고분자 구조체를 DLP 혹은 SLA로 제작하고, 소 결을 통해 세라믹으로 직접 변환한 고분자 유래 세라믹 (polymer-derived ceramics, PDC) 프린팅 기술을 선 보였다.

이 연구는 무엇보다도 $\mathrm{PDC}$ 라는 세라믹 소재 기술 을 환기시키는 중요한 계기가 되었다. 비록 최신 연 구 동향에서 많이 멀어진 것이 사실이나, $\mathrm{PDC}$ 의 역사 는 1960년대로 거슬러 올라갈 정도로 중요한 세라믹 기 술 중 하나이다. 유기물을 무기물로 변환하려는 연구는 1960년대 초 영국의 Ainger와 Herbert 박사 연구팀, Chantrell과 Popper 박사 연구팀들이 N, P, B, Si 등 이 포함된 유·무기 복합 화합물 및 이들의 올리고머 개 발, 그리고 결정 구조 분석 등을 통해 보고 되었다. ${ }^{28-29)}$ $\mathrm{PCP}$ 의 직접 소결을 통해 $\mathrm{PDC}$ 를 제작하는 연구는 1970 년대 초 독일 Bayer사의 Wolfgang Verbeek 박사 연구 팀이 organosilicone 기반 고분자의 소결을 통한 세라 믹 제작 기술을 최초로 보고하였으며, 이 후 일본 도호 쿠 대학의 Seishi Yajima 교수, 독일 Marburg 대학의 Gerhard Fritz 교수, 이탈리아 Padova 대학의 Paolo Colomno 교수 등 여러 연구팀들이 PDC 기술을 심화시 켰다. ${ }^{30-33)}$ 이들은 organosilane와 organosiloxane등의 실리콘 기반 화합물을 중합하여 $\mathrm{PCP}$ 를 합성하고, 이를 직접 소결하여 $\mathrm{SiC}, \mathrm{Si}_{3} \mathrm{~N}_{4}, \mathrm{SiCN}, \mathrm{SiCBN}$ 등의 $\mathrm{PDC}$ 를
제작하는 기술을 개발하였다.

$\mathrm{PDC}$ 는 세라믹 분말 소결 방법에 비해 여러가지 장점 들을 갖는다. 먼저, $\mathrm{PDC}$ 는 고분자 (분자 단위)가 직접 세라믹으로 변환하기 때문에 분말 (입자 단위)에서 세라 믹으로 변환되는 것 보다 낮은 에너지가 필요하다 (소결 온도가 낮음). 또한, 세라믹 레진에서 반드시 거쳐야 하 는 고분자 탈지 과정이 없기 때문에 소결 후 수축 정도 도 횔씬 낮다. $\mathrm{PCP}$ 는 대부분 점도가 높은 액상으로 존 재하므로, 압출 성형을 통한 섬유와 같은 정교한 구조 제작이 가능하다. 또한, 광경화 $3 \mathrm{D}$ 프린팅 적용 시, 세 라믹 분말에서 나타나는 빛의 산란에 의한 광경화 효율 감소 효과가 없기 때문에 세라믹 레진에 비해 더 정교한 세라믹 구조체를 제작할 수 있다. 이러한 장점들로 인해 Schaedler 박사 연구팀의 보고 이후 세라믹 3D 프린팅 의 새로운 방향으로 매우 큰 주목을 받으며 높은 인용도 와 함께 꾸준한 후속 연구들이 보고되고 있다. ${ }^{34-37)}$

이러한 장점 들에도 불구하고 $\mathrm{PDC}$ 프린팅이 기존의 분말 기반 세라믹 레진 프린팅을 모두 대체하는 것은 불 가능하다. 그 이유는 $\mathrm{PCP}$ 합성이 가능한 소재 군이 한 정적이기 때문이다. 탄소를 제외하고 고분자 합성에 필 수 조건인 타 원소와 공유 결합이 가능하면서 안정하 고 풍부한 원료를 보유한 비금속 원소는 탄소와 같은 14 족 원소인 실리콘이 거의 유일하다 (예외적으로 실리콘 외 비금속중 polyaluminoxane (Al), polyzirconoxane $(\mathrm{Zr})$, poly[(methylamino)borazine] $(\mathrm{B}, \mathrm{N})$ 도 존재하 
(a)
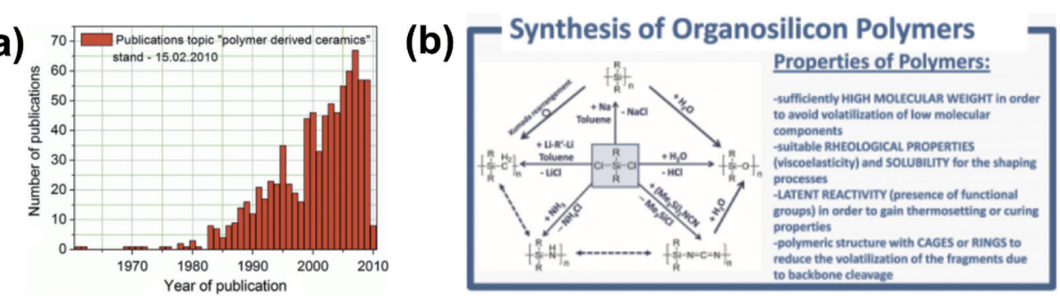

(c)

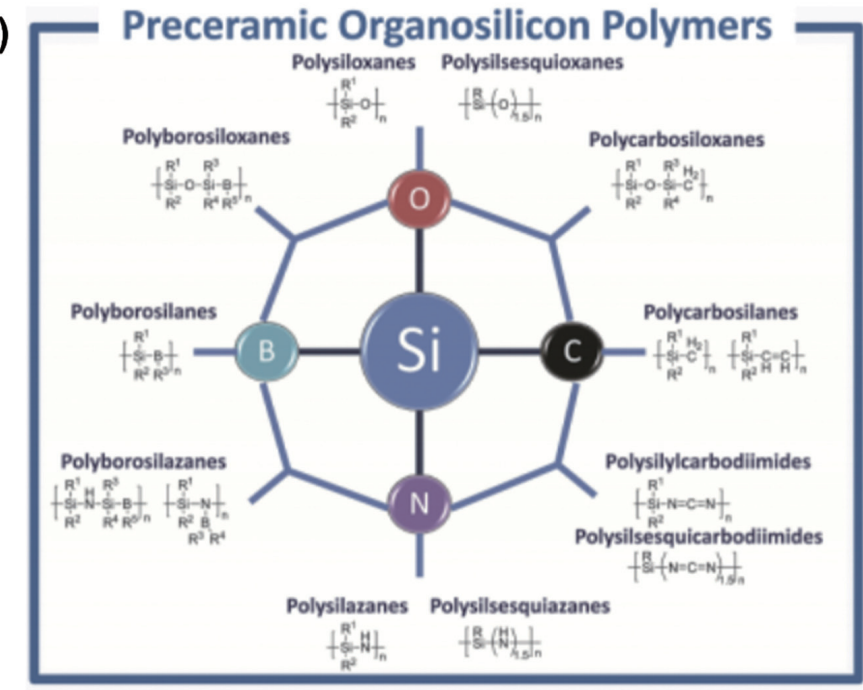

Fig. 11. (a) 연도별 polymer-derived ceramics 관련 출판된 논문 수. (b) Organosilicon 고분자 합성 방법 및 특징 (c) 다양한 organosilicon 고분자 예시. ${ }^{38)}$

나, 합성 기술이 쉽지 않아 실용성이 낮음). 그러므로 $\mathrm{PDC}$ 프린팅은 기존 세라믹 3D 프린팅과 상호 보완적인 관계로 발전해 나갈 것으로 전망된다. 특히 $\mathrm{PCP}$ 과 세라 믹 분말을 혼합한 새로운 개념의 세라믹 레진을 적용한 복합체 세라믹 제작에 특히 유용할 것이다.

\section{4. 결론}

세라믹 $3 \mathrm{D}$ 프린팅 기술은 지난 10년간 플라스틱 제 품 제작을 위한 고분자 기반 $3 \mathrm{D}$ 프린팅 기술의 급격한 발전과 맞물려 최근 활발히 연구가 진행되고 있다. 비 록 기술 성숙도는 타 소재들에 비해 낮으나, 세라믹 $3 \mathrm{D}$ 프린팅 기술 또한 지속적인 발전을 이루고 있으며, 집 적된 기술을 산업적으로 응용하려는 시도들이 계속되 고 있다. 항상 수요가 기술 발전을 유도하는 것은 아니 므로 지속적인 발전을 통해 효율성과 기술력이 극대화
된 세라믹 $3 \mathrm{D}$ 프린팅 기술이 개발된다면, 건축, 자동 차, 항공과 같은 공업 분야에 사용되는 구조 세라믹스 뿐만 아니라, 정밀 부품 산업의 핵심인 전자 세라믹스 (transducer, capacitor, condensor 등), 에너지-환경 세라믹스 (배터리, 연료전지, 필터)과 같은 정교한 복잡 구조가 필수적인 부품 개발로 이어질 것으로 전망된다.

최근 세라믹 $3 \mathrm{D}$ 프린팅의 위상 제고에 큰 역할을 한 분야는 '바이오세라믹스'이다. 골대체재로 실리카, 알루 미나, $\mathrm{CaP}$ 와 같은 세라믹 소재는 이미 오랫동안 사용되 어 왔다. 하지만 최근 재생의학, 조직공학 분야가 미래 의료산업의 새로운 패러다임으로 자리잡으면서, 환자맞 춤형 치료법이 최근 4차산업의 한 축으로 각광받고 있 다. 그러므로 세라믹 $3 \mathrm{D}$ 프린팅을 통해 기존 정형외과 용 골대채제 및 보형물의 한계를 뛰어넘는 환자맞춤형 제품을 제작하는 연구가 매우 활발히 진행되고 있으며, 가까운 미래에 상용화될 것으로 전망된다. 
플라스틱 소재 프린팅과 마찬가지로, 세라믹 3D 프린 팅 기술 또한 지속적인 성장을 통해 보편화로 이어질 것 이다. 이를 통해 과학기술 분야뿐만 아니라 일상 생활에 서 사용하는 가정 용품, 예술품 제작에도 현재보다 더 널리 응용될 것이다. 이 모든 세라믹 3D 프린팅 기술의 발전은 결국 고분자와 세라믹이란 서로 다른 두 소재의 만남을 통해 가능한 것이다.

\section{REFERENCES}

1. Kodama, H., Automatic method for fabricating a three-dimensional plastic model with photohardening polymer. Rev. Sci. Instrum., 52 [11], 1770-73 (1981).

2. Patel, D. K.; Sakhaei, A. H.; Layani, M.; Zhang, B.; Ge, Q.; Magdassi, S., Highly Stretchable and UV Curable Elastomers for Digital Light Processing Based 3D Printing. Adv. Mater., 29 [15], 1606000 (2017).

3. Hull, C. W. Apparatus for production of threedimensional objects by stereolithography. US 4,575,330, 1986 .

4. Chen, Z.; Li, Z.; Li, J.; Liu, C.; Lao, C.; Fu, Y.; Liu, C.; Li, Y.; Wang, P.; He, Y., 3D printing of ceramics: A review. J. Eur. Ceram. Soc., 39 [4], 661-87 (2019).

5. Hwa, L. C.; Rajoo, S.; Noor, A. M.; Ahmad, N.; Uday, M. B., Recent advances in 3D printing of porous ceramics: A review. Curr. Opin. Solid State Mater. Sci., 21 [6], 323-47 (2017).

6. Bae, C.-J.; Ramachandran, A.; Chung, K.; Park, S., Ceramic Stereolithography: Additive Manufacturing for 3D Complex Ceramic Structures. J. Korean Ceram. Soc, 54 [6], 47077 (2017).

7. Marcus, H. L.; Beaman, J. J.; Barlow, J. W.; Bourell, D. L., Solid freeform fabrication. Powder processing. Am. Ceram. Soc. Bull, 69 [6], 1030-31 (1990).

8. Sachs, E.; Cima, M.; Cornie, J., ThreeDimensional Printing: Rapid Tooling and Prototypes Directly from a CAD Model. CIRP Annals, 39 [1], 201-04 (1990).

9. Griffith, M. L.; Halloran, J. W. In
Ultraviolet curable ceramic suspensions for stereolithography of ceramics, American Society of Mechanical Engineers, Production Engineering Division (Publication) PED, pp. 529-34 (1994).

10. Griffith, M. L.; Halloran, J. W., Freeform fabrication of ceramics via stereolithography. J. Am. Ceram. Soc., 79 [10], 2601-08 (1996).

11. Brady, G. A.; Halloran, J. W., Stereolithography of ceramic suspensions. Rapid Prototyping Journal, 3 [2], 61-65 (1997).

12. Badev, A.; Abouliatim, Y.; Chartier, T.; Lecamp, L.; Lebaudy, P.; Chaput, C.; Delage, C., Photopolymerization kinetics of a polyether acrylate in the presence of ceramic fillers used in stereolithography. J. Photochem. Photobiol. A: Chem., 222 [1], 117-22 (2011).

13. Zanchetta, E.; Cattaldo, M.; Franchin, G.; Schwentenwein, M.; Homa, J.; Brusatin, G.; Colombo, P., Stereolithography of SiOC Ceramic Microcomponents. Adv. Mater., 28 [2], 370-76 (2016).

14. Felzmann, R.; Gruber, S.; Mitteramskogler, G.; Tesavibul, P.; Boccaccini, A. R.; Liska, R.; Stampfl, J., Lithography-Based Additive Manufacturing of Cellular Ceramic Structures. Adv. Eng. Mater., 14 [12], 1052-58 (2012).

15. 송경은, 깨지기 쉬운 세라믹, $3 \mathrm{D}$ 프린터로 한번에 인 쇄한다. 동아사이언스 April 24, 2017.

16. Duan, B.; Wang, M.; Zhou, W. Y.; Cheung, W. L.; Li, Z. Y.; Lu, W. W., Three-dimensional nanocomposite scaffolds fabricated via selective laser sintering for bone tissue engineering. Acta Biomater., 6 [12], 4495-505 (2010).

17. Sing Swee, L., Direct selective laser sintering and melting of ceramics: a review. Rapid Prototyping Journal, 23 [3], 611-23 (2017).

18. Subramanian, K., Selective laser sintering of alumina with polymer binders. Rapid Prototyping Journal, 1 [2], 24-35 (1995).

19. Tang, H.-H.; Chiu, M.-L.; Yen, H.-C., Slurrybased selective laser sintering of polymercoated ceramic powders to fabricate high strength alumina parts. J. Eur. Ceram. Soc., 31 [8], 1383-88 (2011).

20. Guo, D.; Li, L.-t.; Cai, K.; Gui, Z.-l.; Nan, C.-w., Rapid Prototyping of Piezoelectric 
Ceramics via Selective Laser Sintering and Gelcasting. J. Am. Ceram. Soc., 87 [1], 17-22 (2004).

21. Danforth, S., Fused Deposition of Ceramics: A New Technique for the Rapid Fabrication of Ceramic Components. Materials Technology, 10 [7-8], 144-46 (1995).

22. Jafari, M. A., A novel system for fused deposition of advanced multiple ceramics. Rapid Prototyping Journal, 6 [3], 161-75 (2000).

23. Khatri, B.; Lappe, K.; Habedank, M.; Mueller, T.; Megnin, C.; Hanemann, T., Fused Deposition Modeling of ABS-Barium Titanate Composites: A Simple Route towards Tailored Dielectric Devices. Polymers, 10 [6], 666 (2018).

24. Iyer, S.; McIntosh, J.; Bandyopadhyay, A.; Langrana, N.; Safari, A.; Danforth, S. C.; Clancy, R. B.; Gasdaska, C.; Whalen, P. J., Microstructural Characterization and Mechanical Properties of Si3N4 Formed by Fused Deposition of Ceramics. International Journal of Applied Ceramic Technology, 5 [2], 127-37 (2008).

25. Mohanty, S.; Larsen, L. B.; Trifol, J.; Szabo, P.; Burri, H. V. R.; Canali, C.; Dufva, M.; Emnéus, J.; Wolff, A., Fabrication of scalable and structured tissue engineering scaffolds using water dissolvable sacrificial 3D printed moulds. Materials Science and Engineering: $C$, 55, 569-78 (2015).

26. Wen, Y.; Xun, S.; Haoye, M.; Baichuan, S.; Peng, C.; Xuejian, L.; Kaihong, Z.; Xuan, Y.; Jiang, P.; Shibi, L., 3D printed porous ceramic scaffolds for bone tissue engineering: a review. Biomaterials Science, 5 [9], 1690-98 (2017)

27. Eckel, Z. C.; Zhou, C.; Martin, J. H.; Jacobsen, A. J.; Carter, W. B.; Schaedler, T. A., Additive manufacturing of polymer-derived ceramics. Science, 351 [6268], 58-62 (2016).

28. Ainger, F. W.; Herbert, J. M., The Preparation of Phosphorus-Nitrogen Compounds as NonPorous Solids. Academic Press: New York, pp. 168-182 (1965).

29. Chantrell, P. G.; Popper, P., Inorganic
Polymers and Ceramics. Academic Press: New York, pp. 87-103 (1965).

30. Jansen, M.; Jüngermann, H., A new class of promising ceramics based on amorphous inorganic networks. Curr. Opin. Solid State Mater. Sci., 2 [2], 150-57 (1997).

31. Fritz, G.; Raabe, B., Bildung siliciumorganischer Verbindungen. V. Die Thermische Zersetzung von $\mathrm{Si}(\mathrm{CH} 3) 4$ und $\mathrm{Si}(\mathrm{C} 2 \mathrm{H} 5) 4$. Z. Anorg. Allg. Chem., 286 [3-4], 149-67 (1956).

32. Seishi, Y.; Josaburo, H.; Mamoru, O., Continuous silicon carbide fiber of high tensile strength. Chem. Lett., 4 [9], 931-34 (1975).

33. Riedel, R.; Passing, G.; Schönfelder, H.; Brook, R. J., Synthesis of dense silicon-based ceramics at low temperatures. Nature, 355 [6362], 714-17 (1992).

34. Liu, G.; Zhao, Y.; Wu, G.; Lu, J., Origami and $4 \mathrm{D}$ printing of elastomer-derived ceramic structures. Science Advances, 4 [8], eaat0641 (2018).

35. Fu, Y.; Chen, Z.; Xu, G.; Wei, Y.; Lao, C., Preparation and stereolithography 3D printing of ultralight and ultrastrong $\mathrm{ZrOC}$ porous ceramics. J. Alloys Compd., 789, 867-73 (2019).

36. Wang, M.; Xie, C.; He, R.; Ding, G.; Zhang, K.; Wang, G.; Fang, D., Polymer-derived silicon nitride ceramics by digital light processing based additive manufacturing. $J$. Am. Ceram. Soc., 102 [9], 5117-26 (2019).

37. Wang, X.; Schmidt, F.; Hanaor, D.; Kamm, P. $\mathrm{H}_{\text {. }}$ Li, S.; Gurlo, A., Additive manufacturing of ceramics from preceramic polymers: A versatile stereolithographic approach assisted by thiol-ene click chemistry. Additive Manufacturing, 27, 80-90 (2019).

38. Colombo, P.; Mera, G.; Riedel, R.; Sorarù, G. D., Polymer-Derived Ceramics: 40 Years of Research and Innovation in Advanced Ceramics. J. Am. Ceram. Soc., 93 [7], 1805-37 (2010). 


\section{○。차 채녕}

O 2007년 한국과학기술원 학사
O 2011년 University of Illinois, Urbana-
Champaign 박사

